\title{
Bevezető az információs társadalom tudománytörténetéhez
}

A szerző kísérletet tett arra, hogy egy, a legújabb európai kutatásokat felölelő, jegyzetekkel is ellátott bibliográfiát állítson össze. A rövid könyvismertetők előtt az európai és az amerikai információs társadalommal kapcsolatos kutatások ellentmondásainak és eredményeinek rövid összefoglalása olvasható. A kritikai igényű írás rávilágít az eltérő kutatási módszerek hiányosságaira, illetve szembeállítja az amerikaiak és az európaiak módszertanát, hozzáállását és eredményességét az információs társadalommal kapcsolatos kutatásokban.

\section{Szerzői információ:}

Philip E. Agre az információtudomány docense a Kalifornai Egyetemen (UCLA). Számos amerikai egyetemen és Párizsban is tartott előadásokat, kurzusokat. Jelenlegi kutatásai megerősítik az információs technológiák egyre növekvő szerepét az intézmények szerkezeti átalakulásában, amelyek kihatnak az adatvédelemre és az egyetemi hálózatokra is. A hálózatépítés és a programozás társadalmi és politikai aspektusainak megtárgyalására létrehozta a Red Rock Eater News Service elnevezésủ Internetes levelezőlistát, amely hatvan országban több, mint ötezer ember számára nyújt hasznos információkat.

Fontosabb könyvei: Computation and Human Experience, Cambridge University Press, 1997; Technology and Privacy: The New Landscape társszerző: Marc Rotenberg; MIT Press, 1997; Reinventing Technology, Rediscovering Community: Critical Studies in Computing as a Social Practice, társszerző: Douglas Schuler; Ablex, 1997; Computational Theories of Interaction and Agency társszerző: Stanley J. Rosenschein; MIT Press, 1996.

\section{Így hivatkozzon erre a cikkre:}

Agre, Philip E. „Új európai kutatások az információs társadalomról”. Információs Társadalom I, 1. szám (2001): 49-55.

$=$ https://dx.doi.org/10.22503/inftars.I.2001.1.3 $\rightleftharpoons$

A folyóiratban közölt müvek a Creative Commons Nevezd meg! - Ne add el! - Így add tovább! 4.0 Nemzetközi Licenc feltételeinek megfelelöen használhatók. 
PhILIP E. Agre:

\section{ÚJ EURÓPAI KUTATÁSOK AZ INFORMÁCIÓS TÁRSADALOMRÓL}

Mára már globális iparrá nốtte ki magát az információs-kommunikációs technológia (information and communication technologies, a továbbiakban ICT) szerepének kutatása a társadalmi változásokban. Az amerikaiak, itt is azt feltételezik, hogy ezen a területen is az Amerikai Egyesült Államok jár az élen. Az elmúlt év során megjelent publikációkból azonban egyértelmúen kiderül, hogy a kutatások élmezőnyei Európában találhatóak. Az alábbiakban, egy a legújabb európai kutatásokat felöleló, jegyzetekkel is ellátott bibliográfiát állítottam össze. Ezt megelőzően azonban, hadd vázoljak fel néhány általános gondolatot az információs társadalommal kapcsolatos amerikai és európai kutatásokról.

Az amerikaiak mindig az „Internet”-ről beszélnek, de közben elég tágan és következetlenül használják ezt a fogalmat; melyet azért is szeretnek, mert saját találmányuknak tartják. Az európaiak az „információs-kommunikációs technológiáról”, vagyis az ICT-ról beszélnek, ami az Internetnél sokkal több, mindent magába foglaló, pontosabb fogalom. Egyrészt, olyan területek is beletartoznak, mint például a távközlés melyben szintén elóbbre vannak az európaiak; másrészt feltételezi, s így mellőzésével nem sérti meg a postai és telekommunikációs bürokráciát.

Az amerikai kutatás, az egyetem keretein belül maradva, fóleg a diplomamunkájukat készító egyetemisták egyéni munkáján alapszik - bár a nagyobb, több intézményre kiterjedő, ún. multi-site projektek is egyre általánosabbá válnak. Az európai kutatások ezzel szemben a kollektív, több intézmény együttmúködésével zajló projektekre épülnek, amelyek azonban elég erősen az ơket finanszírozó szervezetek irányítása alatt állnak. Többek között ez magyarázza azt meg, hogy miért múködik jobban az amerikai egyetemi rendszer, mint az európai, illetve azt, hogy az európai társadalomtudományi kutatások miért tudtak hatékonyabban más, egyetemen kívüli intézményekbe integrálódni.

Az amerikai kutatások két fő́bb csoportra oszlanak: egyrészt azokra, amelyeket az NSF (National Science Foundation, azaz Nemzeti Tudományos Alap) támogat, ami, ha a hálózati és az adatbázis projektek mellett, ha azok pénzügyi feltételei már biztosított, társadalomtudományi kutatásokat is hajlandó finanszírozni. Másrészt pedig a magánalapítványok által folytatott kutatásokra. Ezek az alapítványok egyre nagyobb mértékben (bár nem kizárólagosan) saját projekteket futtatnak, amelyeket rendszerint közvetlenül saját irányelveik határoznak meg, s nem mások kutatásait támogatják. Európában ezzel szemben az Európai Unió elkötelezettje az információs társadalom vizsgálatának, amely teljes mértékben a szervezet politikaformálási folyamatának a részét is képezi. Figyelemre méltó, hogy mind az amerikai, mind az európai kutatásokat támogató szervezeteket jól képzett, értelmes emberek vezetik.

Az amerikai kutatások sokkal kreatívabbak, míg az európaiaknak az intézményi megalapozottságuk jobb. Az amerikaiak kiemelkedóbb eredményeket értek el a szigorú, tényeken alapuló közgazdaságtanban (hard economics), az európaiak azonban az intézményszintû közgazdaságtanban (institutional economics) jeleskednek. Az amerikaiak a mérnöki tervezésben, míg az európaiak a múvészetekből és a demokratikus beállítottságukból eredő tervezési módszerekben jutottak el magasabb szintekre. Az amerikaiak jobbak az etnográfiában és a szervezetekre kiterjedő vizsgálatokban, az európaiak viszont az ipari régiók és a széleskörú társadalmi tendenciák tanulmányozásában. Az amerikai elméletek sokkal inkább divatvezéreltek, az európaiakat pedig inkább a tradíciók befolyásolják. Az amerikai kutatók figyelmét fốleg a „cyber hype” köti le - akár propagálják, akár elutasítják azt; az európaiakét viszont az EU irányelvei.

Az amerikai kutatások régóta küszködnek azzal, hogy megszabaduljanak a technológiai determinizmustól. Nehézséget okoz például a „cyberspace” fogalma, amely egyrészt egy különálló tartományt jelöl, ugyanakkor magában hordja azzal a múlttal való forradalmi szakítást, amelyben a szabályokat még egyszerúen a gépezet múködése diktálja. Az európaiaknak kevesebb ilyen típusú problémájuk van, hisz ők olyan „információs társadalomról” beszélnek, amelyben minden folytatólagos. Terjedelmes és fárasztó dokumentációt készítenek az irányelveikról, amelyben mindennek megvan a maga helye. Az amerikaiak nem kedvelik az ilyen típusú dokumentációt, s épp ezért az amerikai gondolkodás több szempontból - minden kreativitása ellenére - sem egységes.

Az amerikaiak sokkal összetettebb, technológia-vezérelt társadalmi szokásokat vizsgálhatnak meg, mivel széleskörúen kiépített információs közmúvel rendelkeznek. Legfớképp azért, mert az USA tudományos élvonala - élen az ARPA-val, de ide tartozik az NSF vezetô rétege, a nagy szuperszámítógép laboratóriumok, és az IBM is - rendkívül képzett és jól szervezett. (A Szilícium-völgy nagy port kavar ugyan, de a technoló- 
giai fejlesztés irányába nem tesz lépéseket.) Az európaiak azonban a standardok felállításában, valamint az iparpolitikában jeleskednek, iparágazatokat támogatnak, mint például Skandináviában a távközlési ipart. (A mi iparpolitikánk az, hogy nagy professzorokat szerződtetünk a cégek beindításához. És ez múködik is. Máskülönben, számos amerikai fennhatóságnak üres és költséges elképzelései vannak arról, hogy hogyan szerezze meg a maga Szilícium-völgyét.) Az európai kutatásokat elsősorban az ipari irányelvek befolyásolják. Amerikában digitális könyvtárkutatást találsz, - amelyról a Szilícium-völgyben alig hallottak, hiszen fóleg Kaliforniára összpontosítanak - Európában pedig mobiltelefon használókra irányuló vizsgálatokat. A mobilizált távközlés most változtatja meg a világot, a digitális könyvtárak pedig tíz éven belül szintén változást fognak előidézni. Mindkét terület alapos, társadalmi szempontú vizsgálatot igényel.

Az új technológiáknak a társadalmi egyenlőségre gyakorolt hatása nagy aggodalmat vált ki mind az európai, mind az amerikai közvéleményben.. Az európaiak kiemelkedőek a fogalomalkotásban. Az amerikaiak által használt „digitális megosztottság” (digital divide) és az „információval bírók és azt nélkülözók” (information haves and have nots) aligha nevezi nevén a problémát, még kevésbé mutat a jó megoldás felé. Az európaiak által használt „társadalmi bennfoglalás és kirekesztés” (social inclusion and exclusion), annak ellenére, hogy sokaknak úgy hangzik, mintha valaki a táblán húzná végig a körmét, előremutat, és szélesebb kontextusba helyezi az ICT-t. Az európaiak biztos kifogásolni fogják, hogy nem vagyok elég pontos az európai válaszpolitika felvázolásában, de itt csupán az USA-val való összehasonlítás a célom.

Egyaránt nehéz az amerikai- és az európai kutatásokról szóló jelentéseket megszerezni. Az amerikaiakat azért, mert számos olyan új folyóiratban jelennek meg, amelyekhez nehéz a könyvtárakban hozzájutni. Az európai kutatásokról szóló jelentéseket pedig azért, mert elsősorban az őket támogató szervezetek számára készülnek.

Utolsó ellentmondás: A félreértések elkerülése végett: én nem azt állítom, hogy az európai információs társadalom - kutatások értékesek, az összes amerikai pedig értéktelen. Épp ellenkezóleg, az EU hivatali munkája számos semmitmondó szakértői beszámolót is termel, szemben a magas színvonalú amerikai kutatásokkal.

Az általánosítások után pedig következzen:

\section{Az információs társadalommal kapcsolatos európai kutatások jegyzetekkel ellátott bibliográfiája}

Egy-két kivételtốl eltekintve, leginkább az új kiadványokra összpontosítottam, (inkább, mint a régi kiadványokra, cikkekre vagy könyvfejezetekre), néhány kivétellel ez a lista semmi esetre sem teljes, akár duplájára is lehetne növelni.

Antonelli, C.: New information technology and the evolution of the industrial organisation of the production of knowledge. In: Information and Organization: A Tribute to the Work of Don Lamberton, (Szerk.: Stuart Macdonald and John Nightingale), Amsterdam: North-Holland, 1999.

Igényes elméleti beszámoló arról, hogy milyen szerepet játszanak a hálózati információs szolgáltatások az ipari struktúra alakulásában. Az alapötlet olyan közgazdasági képzettséggel rendelkezó, menedzsmenttel foglalkozó szakemberek közösségétől származik, akik a technikai felépítés és az ipari struktúra közti kölcsönhatást tanulmányozzák. Bár ezen a területen Amerikában is jó eredményeket értek el, Antonelli cikke páratlan a maga nemében.

Bliss, J., Saljo, R., \& Light, P. (szerk.):

Learning Sites: Social and Technological Resources for Learning.

Oxford: Pergamon, 1999 .

L. Sz. Vigotszkij, orosz pszichológus oktatási elvein alapuló érdekes gyújtemény a tanulási technikáról. (Amerikában szintén folynak hasonló, jó minôségú kutatások az oktatástechnológiáról, mint például a San Diedo-i Egyetemen.) 
Bodker, S., Kyng, M., \& Schmidt, K. (szerk.):

Proceedings of the Sixth European Conference on Computer Supported Cooperative Work.

Dordrecht: Kluwer, 1999.

A „számítógépes kooperatív munka” (Computer Supported Cooperative Work, a továbbiakban (SCW), ahogy a könyv címe is utal rá, a kooperatív munkát elősegítő technikai eszközök kifejlesztésével foglalkozik. Kiderül, hogy a csoportos használatra készített eszközök kudarcot vallanak a csoportmunka társadalmi oldalának mélyreható ismerete nélkül. Ezért a CSCW kutatásnak még talán más szakterületeknél is nagyobb mértékben kell a technikai és társadalomtudományi oldalt összehangolnia. Ez azért is nehéz, mert a múszaki szakemberek és a társadalomtudósok, úgymond, más-más bolygón élnek. Konferencia keretein belül a két oldal megvitathatná az együttmúködés feltételeit. Mind az amerikaiak, mind az európaiak próbálnak felülkerekedni a nézeteltéréseken, de az utóbbiak mindezidáig több sikerrel jártak.

Bjerknes, G., Ehn, P. \& Kyng, M. (szerk.):

Computers and Democracy: A Scandinavian Challenge, Aldershot.

UK: Avebury, 1987.

Bár ez a könyv már réginek számít, mégis felvettem a bibliográfiába, mivel ez az egyik első manifesztuma az 1970-es években, Norvégiában induló „résztvevő tervezési mozgalomnak” (participatory design movement), ami azóta már egész Skandináviában intézményesített keretek között folyik. A legelsố projektekben még csak szakszervezeteket vontak be a munkahelyi technológia megtervezésébe, késóbb a mozgalom általános érvényứ tervezési kultúrává nőtte ki magát, melynek célja a felhasználók tervezési folyamatba való bevonása. Ez egyben azt is jelenti, hogy szembe kell nézni azzal, hogy a „felhasználók nem tudják, mit akarnak", valamint egy demokrácia kormányzati-szabályozási folyamataiban felszínre kerülő következményekkel, amelyeket a tervezés vitathatatlan politikai természete von maga után. Nem egészen értem, hogy az elmúlt évek során, miért jelent meg olyan kevés kötet, illetve elméleti munka a „résztvevő tervezéssel” kapcsolatban. Kutatások jelenleg is folynak, ahogy azt a Konferencia a „résztvevő tervezésról” közleményei is mutatják. Ez a terület sokkal nagyobb annál, hogy a skandináv országok egyszerúen túllépjenek rajta.

Braczyk, H.-J., Fuchs, G. \& Wolf, H-G. (szerk.):

Multimedia and Regional Economic Restructuring.

London: Routledge,1999.

Ez talán az egyik legalaposabb tanulmánygyưijtemény az információs technológia gazdaságföldrajzra gyakorolt hatásairól.

Casson, M.: Information and Organization:

A New Perspective on the Theory of the Firm.

clarendon Press, 1997.

Az információnak az ipari szervezetben betöltött helyéról való újszerû elméleti analízis. A közgazdaság-tudományban világszerte a neoklasszikus iskola a mérvadó. Nagy-Britanniában azonban számos, a neoklasszikus irányzattól eltérő nézeteket valló közgazdász él, s közülük Casson könyve azért érdekes, mert ő a neoklasszikus és az intézményesített hagyományos tábor között áll. Ebben a könyvében abból az elméletból indul ki, hogy minden gazdasági szervezetnek egyfajta közvetítő szerepe van a dolgozók, mint önálló személyek és a fogyasztók, mint önálló személyek között. Ebben a közelítésben minden szervezet létét meg lehet indokolni. A közvetítő szerep egyik lehetséges módja az információgyújtés és feldolgozás. E sajátos gondolkodásmóddal néhány egyszerú megfigyelés is sokféle, érdekes következtetést, vagy legalábbis hipotézist eredményezhet. 
Ciborra, Cl. U. (szerk.):

From Control to Drift: The Dynamics of Corporate Information Infrastructures.

Oxford: Oxford University Press, 2000.

Az oslói project az IT standardok szervezeti szintû́ megvalósulásáról ír. Néhány esettanulmányban különböző európai vállalat esetében meghiúsult standardizációs projekteket összegez, melyekben a hálózati közgażdaságtant (network economics) és az ún. „actor-network” elméletet alkalmazták. Az új standardokra, - mint például az Internetre - való áttérés néhány nagyvállalatnál elkerülhetetlenül vállalatpolitikai és logisztikai összevisszaságot eredményezett.

Criddle, S., Dempsey, L. \& Heseltine, R. (szerk.):

Information Landscapes for a Learning Society.

London: Library Association, 1999.

Ez a könyv többnyire a brit könyvtárak új típusú kezdeményezéseirôl szóló beszámolók gyüjteménye. Az információs szolgáltatásoknak az új digitális világnak megfelelő átformálásában a britek járnak az élen. Például könyvtári szolgáltatásokat ötvöznek oktató jellegú média-szolgáltatásokkal, és hasonlóképpen járnak el a felsőoktatásban is.

Ducatel, K., Webster, J. \& Herrmann, W. (szerk.):

The Information Society in Europe: Work and Life in an Age of Globalization.

Rowman and Littlefield, 2000.

Ez a kötet jó példa arra, amikor az információs társadalommal kapcsolatos, kritikai igénnyel végzett kutatás az EU égisze alatt zajlik anélkül, hogy annak tartalmát a hivatali gépezet bármilyen módon befolyásolná. A kötet szerzője kiindulásként tisztán megragadja a földünkön funkcionáló információs társadalom sokdimenziós konkrét realitását. A témák között szerepel: területfejlesztés, új szerveződési formák, a munkaerópiac, és az ICT alkalmazása az egészségügy, az oktatás és a politika területén.

Dunne, A.: Hertzian Tales: Electronic Products,

Aesthetic Experience and Critical Design.

Art Books, 2000.

Ez a könyv a Londoni Szépmúvészeti Egyetem egyik diplomamunkáján alapszik. Maga az egyetem az egyik legérdekesebb szülőhelye a digitális termékek müvészi tervezésének. A könyv szerintem túlságosan belemélyed a divatelméletbe; és számomra nem elfogadható mértékben veszi komolyan Baudrillard-t. Elgondolkodtató és gyakran zavarba ejtő. De ugyanakkor komoly és helytálló vizsgálata a digitális termékek valódi természetének, és föleg annak a különös problémának, hogy mi is az az objektum, amely fizikai létformát ad az információnak.

Dutton, W. H.: Society on the Line: Information Politics in the Digital Age.

oxford: Oxford University Press, 1998.

Ugyan a szerző amerikai, maga a könyv az Egyesült Királyságban folytatott kutatások összegzése és szintézise. A kutatásokat, mint számos más értékés munkát, a Közgazdaság-és Társadalomtudományi Kutatások Bizottsága (Economic and Social Research Council, továbbiakban ESRC) támogatta.(A legújabb általuk szponzorált projekt, Steve Woolgar vezetése alatt, a Virtuális Társadalom néven fut. Bôvebb információ: <http://virtualsociety.sbs.ox.ac.uk/>). A könyv témáját kijelölő kulcs-fogalom a tele-elérés (teleaccess), amely nem más, mint azok a társadalmilag kialakított körülmények, amelyekben az emberek különböző típusú technológiához és információhoz hozzáférnek. Ez magába foglalja: a személyi- és adatvédelmet, a szólásszabadsággal kapcsolatos kérdéseket, a technológiához való hozzáféréssel kapcsolatos jog- 
egyenlőségi problémákat, és így tovább. A szerző eredményei mellett, a projektben résztvevő́k rövidösszefoglalói is megtalálhatóak a könyvben.

Hawkins, R., Mansell, R. \& Skea, J. szerk.: Standards, Innovation and Competitiveness: The Politics and Economics of Standards in Natural and Technical Environments.

Aldershot, UK: Elgar, 1995.

Ez a standard dinamikáról szóló könyv egy a sok közül az SPRU listáról (ld. $<$ http://www.susx.ac.uk/spru/>). Az SPRU a Sussexi Egyetem kutatói központja, amely ugyan Science Policy Research Unit, (vagyis Tudománypolitikai Egység) néven vált híressé, de ma már Science and Technology Policy Research (Tudomány- és Technológia-politikai Kutatói Központ) a neve. Mint a legtöbb SPRU munka, ez a könyv is az alapjául szolgáló esettanulmányok anyagának hosszabb taglalása nélkül épül fel.

Hoff, J., Horrocks, I. \& Tops, P. szerk.:

Democratic Governance and New Technology:

Technologically Mediated Innovations in Political Practice in Western Europe.

London: Routledge, 2000.

Ismereteim szerint ez a legjobb munka az információtechnológia és a demokrácia kapcsolatáról. A többi technológia és a demokrácia kapcsolatáról szóló európai munkának, ennek a könyvnek is abban rejlik az erőssége, hogy - a választói és törvényhozói rendszerekkel ellentétben - a demokrácia elméleti oldaláról és a közigazgatás gyakorlati oldaláról egyaránt megalapozott. A könyv elején található rövid és tömör fejezetek nagyszerüen vázolják fel, hogy milyen kapcsolat van az „Internet-demokráciáról” alkotott különböző elképzelések, és a demokrácia történetfilozófiai irányzatai - mint például a korporatizmus és a republikanizmus - között. A könyv sajnos túlságosan is az információs politika virtuális valóság „cyberspace” elméletének csapdájába esik ahhoz, hogy egy jól megalapozott, alternatív elmélet szülessen belőle. Ugyanakkor e könyv alapos tanulmányozásán keresztül vezet az út előre.

Az ACM Magazin 1999. november / december havi „Interakciók” című különkiadása beszámol a Maypole néven futó EU projektről, amely a családi fotókkal és azok digitális médiába való vándorlásával foglalkozik. Az EU már korábban is mindent elkövetett, hogy e tárgyban hatékony nemzetközi kutatóprogramokat szervezzen. Az ACM Magazin különszámának egységes grafikai kivitelezése is tükrözi a projekt összehangoltságát. Az együttmúködés effajta magas szintú kultúrája lehetővé teszi, hogy a projekt produktív módon szelje át a diszciplináris határokat. Például családi fotók etnográfiai vizsgálatát ötvözi a családok számára hasznos termékek és szolgáltatások ipari formatervezésének tanulmányozásával. (További információ: <http://www.acm.org/pubs/contents/journals/interactions/1999-6/\#6>). Különösen figyelmükbe ajánlom Dick Rijken, „Információ a térben: felfedező út a médiábạn és az építészetben” („Information in space: Explorations in media and architecture") címủ cikkét.

Ishida, T. \& Isbister, K. (szerk.):

Digital Cities: Technologies, Experiences, and Future Perspectives.

Berlin: Springer, 2000.

Japán és amerikai szerkesztésben készült könyv fő témája: az európai civilhálózati mozgalom (civic networking movement), amely sokkal nagyobb támogatottságot élvez a városi önkormányzatok és társadalmi mozgalmak részéről, mint a közösségi hálózati rendszer (community networking system) az Egyesült Államokban. A legjobb fejezet az ausztrál Bill Mitchell által írt erősen elméleti rész, s bár a legtöbb fejezet projektleírás, az összhatás alapvetően pozitív. 


\section{Liberty, Liberating Cyberspace:}

Civil Liberties, Human Rights and the Internet.

London: Pluto, 1999.

A polgári szabadságjogok és emberi jogok Internettel kapcsolatban felmerülő kérdéseit taglaló, értékes munka. A felsorolt problémák jól ismertek (szerzői jog, kriptográfia, tartalomszabályozás stb.), s a lista ugyan nem sokban különbözik az amerikaitól, kontextusbeli eltérések mégis vannak: az európai és globális szintû emberjogi mozgalom más filozófiai és társadalmi alapot nyújt az analízishez, mint az alkotmányra támaszkodó analízis az USA-ban.

Mansell, $R$. \& Silverstone, $R$. (szerk.):

Communication by Design: The Politics of Information and Communication Technologies.

oxford: Oxford University Press, 1996.

Ismét egy nagyon jó könyv az SPRU listájáról, melynek központi témája : a politikai és a gazdasági tényezők befolyása a társadalom-standardizálási folyamatokra olyan területeken, mint például az elektronikus kereskedelem. Ami nagyon mély benyomást keltett bennem, az nem is annyira a szerzők elméleteinek merészsége, hanem inkább az esettanulmányok mennyisége, amelyeken az analízis alapszik. Mansell és Silverstone jelenleg a Londoni Közgazdaságtudományi Egyetemen dolgoznak.

Mansell, R. \& Steinmueller, W. E.:

Mobilizing the Information Society: Strategies for Growth and Opportunity.

Oxford: Oxford University Press, 2000.

Ez a kötet az SPRU által az elmúlt években, az információs társadalom témakörében elvégzett, EU által támogatott kutatásait foglalja össze. Bár egészében véve is értékes munka, mégis a legérdekesebb az, ahogy a közvetítỏi szerep megváltozásáról ír az információs társadalom ipari struktúrájában. Közismert, hogy a közvetítői szerep megszúnésérôl alkotott elmélet nem helyes; (At USA-ban korábban egyes közgazdászok feltételezték, hogy az Internet közvetlen kapcsolatot teremt az értéklánc nem szomszédos szereplői között, így egyes, közvetítői szerepkört betöltő egységek funkciója feleslegessé válik. - A Szerk.) néhány Amerikában végzett kutatás elméletileg is megalapozta a közvetítés új mintáinak tanulmányozását, de a valós esetek legalaposabb és leghelytállóbb vizsgálatát az SPRU végezte el.

Mansell, R. \& Wehn, U. (szerk.):

Knowledge Societies: Information Technology for Sustainable Development.

New York: Oxford University Press, 1998.

Ez a kötet - mely ismételten egy SPRU tanulmány - egy nagyarányú együttmúködési projekt szintézisét adja, amely az információs technológiának a harmadik világ fejlődésében játszott szerepével foglalkozik. Roppant nagy igény van ilyen információkra, és a kötet tartalmazza a legfontosabb kutatási eredményeket.

Tsagarousianou, R., Tambini, D. \& Bryan, C. (szerk.):

Cyberdemocracy: Technology, Cities and Civic Networks.

London: Routledge, 1998.

Elméleti könyv az európai civilhálózati mozgalomról (civil networking movement). Az Egyesült Királyságban, Olaszországban, Görögországban, Németországban, Hollandiában, valamint egy az USA-ban végzett projektekról szóló fejezeteket tartalmaz. Túlzásoktól és szkepticizmustól egyaránt mentes. 
Van de Donk, W.B.H.J., Snellen, I. Th. M. \& Tops, P. W. (szerk.):

orwell in Athens: A Perspective on Informatization and Democracy.

Amsterdam: IOS Press, 1995.

Komoly és gondos munka a közigazgatásban használatos információtechnológiáról. Mint a fentebb említett másik Hoff, Horrocks és Tops által írt kötet - Technologically Mediated Innovations in Political Practice in Western Europe - (nem véletlen egybeesés, hogy szintén holland csoport jegyezte), ez is mélyreható és ésszerű demokrácia-elméleti ismereteket próbál alkalmazni az információs technológia közigazgatásban felmerülő, gyakorlati problémáinak széles skáláján. Így például: az átlagpolgárok bevonása a hivatali döntésfolyamatba, a közérdekú információk elérhetősége, a különböző forrásokból származó adatok egyesítése, valamint a számítógépes hálózaton keresztül a társadalom kormányzáshoz való hozzáférés. (Wim van de Donk társszerzóje még az alábbi könyveknek: Stephen Coleman-nel and John Taylorral együtt: Parliament in the Age of the Internet, Oxford University Press, 1999, illetve Ig Snellennel együtt: Public Administration in an Information Age: A Handbook, Amsterdam: IOS Press, 1998. Sajnos egyikhez sem sikerült még hozzájutnom.)

Van Dijk, J.: The Network Society:

Social Aspects of New Media. (forditotta: Leontine Spoorenberg),

London: Sage, 1999.

Az új média révén felmerülő társadalmi problémák eddigi legátfogóbb felmérése. Gondos és logikusan levezetett elméleti munka mindenféle részrehajlás nélkül. Ha tanítanék, és túl szeretnék lépni a szkeptikusok és túlzók unalmas okoskodásán, ezt adnám fel olvasmányként. 